\title{
The feasibility of biology module based on stim-HOTS models
}

\author{
Betty Novia Pramesti a,1,*, Sajidan ${ }^{b, 2}$, Sri Dwiastuti b,3, Eko Setyaningsih c,4 \\ a Master Program of Science Education, Universitas Sebelas Maret, JI. Ir. Sutami 36 A, Surakarta, Central Java 57126, Indonesia \\ - Faculty of Teacher Training dan Education, Universitas Sebelas Maret, Jalan Ir. Sutami 36 A, Surakarta, Central Java 57126, Indonesia \\ c Public Senior High School of Surakarta, Jl. Letjen Sutoyo 18 Surakarta, Central Java Indonesia \\ ${ }^{1}$ noviapramesti@gmail.com*; ${ }^{2}$ sajidan@fkip.uns.ac.id; ${ }^{3}$ dwiastuti54@gmail.com; ${ }^{4}$ mimsilmi@yahoo.co.id \\ * corresponding author
}

\begin{tabular}{|c|c|}
\hline ARTICLE INFO & ABSTRACT \\
\hline $\begin{array}{l}\text { Article history } \\
\text { Received January 10, } 2019 \\
\text { Revised February 15, } 2019 \\
\text { Accepted February 25, } 2019 \\
\text { Published February 27, } 2019 \\
\text { Keywords } \\
\text { Higher-order cognitive skills } \\
\text { Higher-order thinking skills } \\
\text { Stim-HOTS-based module }\end{array}$ & $\begin{array}{l}\text { Based on the need's analysis done, the empowerment of higher-order cognitive skills of } \\
\text { the students in Surakarta was not optimal yet. This research addressed to determine } \\
\text { and describe the feasibility of biology module which was arranged based on Stimulating } \\
\text { Higher-Order Thinking Skills (Stim-HOTS) model. This Research and Development } \\
\text { (R\&D) involved six expert validators, including material validator, module development } \\
\text { validator, language validator, learning instrument validator, and school practitioners. } \\
\text { The results showed that the percentages of the module feasibility were between } 83 \% \\
\text { and } 98 \% \text { which were categorized as very good. Based on the results of the analysis, it } \\
\text { can be implied that the Stim-HOTS-based module can be used as learning resource. } \\
\end{array}$ \\
\hline $\begin{array}{l}\text { Pramesti, B } \\
\text { Stim-HOTS } \\
\text { v5i1.7385 }\end{array}$ & $\begin{array}{l}\text { In, S., Dwiastuti, S., \& Setyaningsih, E. (2019). The feasibility of biology module based on } \\
\text { BI (Jurnal Pendidikan Biologi Indonesia), 5(1), 101-108. doi: https://doi.org/10.22219/jpbi. }\end{array}$ \\
\hline
\end{tabular}

\section{INTRODUCTION}

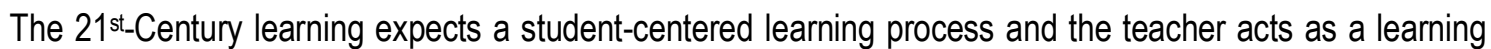
facilitator (Masek, 2019). Student-centered learning can encourage students to follow the learning process more actively(Jabbour, 2013; Keengwe, Onchwari, \& Onchwari, 2009; Lak, Soleimani, \& Parvaneh, 2017). Active learning can facilitate students in building knowledge (Ahn \& Class, 2011; Connell, Donovan, \& Chambers, 2016). This form of learning is considered suitable to be implemented in biology class.

Biology is a part of science whose characteristics of content need to be taught through a constructivist approach (Mwanda, 2017; Singh \& Yaduvanshi, 2015). The constructivist learning principle is the process of building students' knowledge independently and gradually both socially and personally (Bächtold, 2013; Suhendi \& Purwarno, 2018).

Knowledge is obtained in a long period of time, which can be obtained through formal and non-formal education. Initially a person's knowledge must be fragmented and not much, but learning can increase the knowledge gradually, broadly, and interrelated so that a complex concept is obtained (Fisher, 2010). The process of building knowledge is closely related to cognitive processes based on Bloom's taxonomy revised by 
Anderson \& Krathwohl (2015). Cognitive processes equipped with knowledge dimensions will shape the thinking skills or cognitive skills needed in the critical thinking, problem solving and creative thinking processes.

In accordance with the explanation of (Leward \& Hirata, 2011), the learning outcomes expected in the $21^{\text {st }}$. Century include: (a) life and career skills), including the ability to synthesize information, work as a team to manage broadly and complexly and be responsible to the community and the environment; (b) information, media and technology skills and (c) critical learning and innovation skills. The rapid progress in various fields requires Human Resources (HR) with supporting skills not only to compete but also to collaborate, one of which is high-order cognitive skills (Hasan, Naomee, \& Bilkis, 2013; Stanny, 2016; Stayanchi, 2017). High-order cognitive skills in learning can be trained through the selection of methods, models and teaching materials accordance with the indicators of these skills.

Based on the results of observation conducted in school on the teaching material, there are 2 biology textbooks used as the supporting books for the biology learning process. Based on the results of the analysis of book $A$, the indicators of high-order cognitive skills that have not been fulfilled are the score for learning objectives of $2.27 \%$, material of $56.81 \%$, student activities of $6.81 \%$ and evaluation questions of $43.18 \%$. Book $B$ is not much different from book $A$. The acquisition of scores on the learning objectives is $4.45 \%$, on the material is $52.27 \%$, on the student activities is $11.33 \%$ and, on the evaluation, questions is $43.18 \%$. The results of the teaching material analysis are supported by the results of the interviews conducted with the teachers and students showing that both of them need teaching materials that can complement school textbooks that stimulate high-order cognitive skills of the students and facilitate them in the process of understanding the process. The teaching material that can be developed, among others, is a module.

A module one of the teaching materials that has advantages over other materials because it is arranged systematically, intact and planned that help students achieve certain learning goals (Daryanto, 2013). A module has several functions including the independent teaching material, evaluation tool and student literacy source (Dhamija \& Kanchan, 2014; Prastowo, 2011; Rufii, 2015; Serrat et al., 2014). A module as an independent teaching material plays an important role in the learning process, namely by placing students as the subjects of learning so that the learning environment created is active learning without depending on the availability of teachers. The module as an evaluation tool can function as a medium for student reflection about the topic that has been studied. The next role of the module is as a source of literacy, which is related to the contents of the module which consist of materials with a collection of concepts that can be used by the students as learning resources. Through modules arranged in a specific design, teachers can also improve the academic performance of their students (Istiningrum \& Wiyantoko, 2017; Usmeldi, 2018).

The module developed can be based on an appropriate learning model to empower the high-order cognitive skills of the students. The module developed is the Stimulating Higher Order Thinking Skills (Stim-HOTS) model. The Stim-HOTS model is a model designed based on the study of theories of learning about how to teach students' thinking skills and encourage students' freedom of thought wrapped in collaboration, communication and ICT skills (Pramesti, Sajidan, \& Dwiastuti, 2018; Sajidan \& Afandi, 2017; Saputri, Sajidan, Rinanto, Afandi, \& Prasetyanti, 2019). The main principle of the Stim-HOTS model is student-centered learning. The Stim-HOTS model consists of 6 syntaxes, including: (1) Orientation, at this stage the teacher provides the basic concepts of the topic to be studied; (2) Asking, at this stage the teacher directs the students to make a number of questions related to the topic to be studied. The process of making questions made by the students can stimulate their thinking processes in response to cases or problems that occur around them; (3) Information exploration, the activity of the students at this stage is collecting information from various relevant sources by using ICT media, related to the problems they will solve; (4) Discussion, at this stage the students discuss with their group friends, share the results of digging information they have done before, which can train them to communicate the results of information exploration in their groups; (5) explanation, is a class discussion activity that each group presents the results of the group discussion to other groups; (6) Reflection, the final stage in the Stim-HOTS model, at this stage the students reflect on the weaknesses and strengths they encounter during the learning process (Sajidan \& Afandi, 2017).

The biology module based on the Stim-HOTS model developed was indicated empower the high-order cognitive skills of the students. High-order cognitive skills refer to the Bloom taxonomy revised by (Anderson \& Krathwohl, 2001). Anderson and Karthwohl divided cognitive skills into low-order cognitive skills consisting of cognitive processes of $\mathrm{C} 1$ (remembering), C2 (understanding), C3 (applying) and high-order cognitive skill consisting of cognitive processes of $\mathrm{C} 4$ (analysing), $\mathrm{C} 5$ (evaluating) and $\mathrm{C} 6$ (creating). The cognitive process is equipped with a dimension of knowledge consisting of factual, conceptual, procedural and metacognitive knowledge. The Stim-HOTS-based module was developed on cell metabolism topic based on the results of the analysis of the national examination absorptive capacity of public senior high school in Surakarta in that topic experienced a decline from the 2014/2015 to 2016/2017 academic year. The results of this analysis are also supported by the results of the interviews with teachers and students regarding the topic stating that the topic is 
the topic with a broad scope of discussion and there are difficult stages for the students to understand. The students' daily test scores in the topic are also still under the minimum mastery criteria. Cell metabolism topic consists of three sub chapters namely enzymes, catabolism, and anabolism. The concept of cell metabolism topic is the process of energy build up and breakdown. This material consists of many stages of chemical reactions that are often difficult for students to understand so that the existence of a biological module based on the Stim-HOTS model is expected to facilitate students in understanding concepts and empowering high-level cognitive skills to be optimal. Based on the above description, the development of the biology module based on Stim-HOTS model is needed to enhance high-order thinking skills in Surakarta Public Senior High School.

\section{METHOD}

This research applied Research and Development (R \& D) design that refers to the ADDIE model (Branch, 2009). The ADDIE model consists of 5 stages.

\section{Analyse}

This stage includes the data analysis from the results of preliminary research to determine the need for module development. The data from preliminary research results include the analysis of 8 national education standards, the analysis of teacher and student needs, the analysis of learning observation results, the analysis of the absorptive capacity of national examination and the analysis of teaching materials.

\section{Design}

This stage was the preparation stage for the initial drafting of the module based on the Stim-HOTS model and the preparation of the feasibility test procedures. The activities carried out at this stage included the identification of cell metabolism topic from various relevant literatures as the material in the module. After the material had been ready, the module matrix was made consisting of model syntaxes, module activities, the activities expected to appear in students, activity reactions and potential activities towards the high-order cognitive skills of the students. The next step was to make a module design and collect the materials to compile the contents of the module.

\section{Development}

The activities carried out at the development stage were making an initial draft module and conducting the module feasibility test by six expert validators consisting of the material expert validator, module development expert validator, linguist validator, learning instrument expert validators and school practitioners. The qualifications for the validators were the expert lecturers in their fields with the latest level of education of S2 (master's degree) or S3 (doctoral degree) while the practitioners were two biology teachers in Surakarta Public Senior High School.

\section{Implementation}

The implementation stage was the stage carried out after the module was tested for its feasibility by the validators and corrected according to their suggestions. The module was then tested on a small scale, namely on 12 students in Surakarta Public Senior High School to find out the students' responses to the developed module. The students were selected randomly in the same school.

\section{Evaluation}

Evaluation was the step taken to find out the results of the module feasibility test after passing the validation test and small-scale field trial. The module was revised based on the results of the implementation process, and then it was implemented in the field test. The evaluation was conducted with the questionnaire and the results were calculated with the formula adapted from (Arikunto, 2012).

The module developed consists of the teacher module and student module. The instrument used was a questionnaire with a Likert scale in the range of 1 to 4 . The results of the evaluation by the validators, practitioners and students were analysed further using the percentage descriptive technique. The calculation of the validator, practitioner, and student assessment results used the formula adapted from Arikunto (2012) as can be seen in Formula 1.

$\mathrm{P}=\mathrm{K} / \mathrm{Nk} \times 100 \%$

Notes: P: percentage of aspect feasibility; K: result score of data collection, and Nk: maximum score. 
The criteria for making module feasibility decisions can be seen in Table 1.

Table 1. Module feasibility decision making

\begin{tabular}{ccc}
\hline Achievement rate $\%$ & Qualification & Notes \\
\hline $90-100$ & Very Good & No need for revisions \\
$75-89$ & Good & No need for revisions \\
$65-74$ & Enough & Revised \\
$55-64$ & Not good & Revised \\
$0-54$ & Not enough & Revised \\
\hline
\end{tabular}

(Source: Suwastono, 2011)

\section{RESULTS AND DISCUSSION}

\section{Analysis}

\section{The analysis of eight National Education Standards}

This analysis was carried out through interviews with the school principal, head of administrative and biology teachers. The analysis results of eight National Education Standards can be seen in Table 2.

Table 2. Analysis results of eight National Education Standards (NES)

\begin{tabular}{|c|c|c|c|c|c|c|}
\hline \multirow{2}{*}{ Eight standards } & \multirow{2}{*}{$\begin{array}{c}\text { Total of } \\
\text { indicators }\end{array}$} & \multirow{2}{*}{$\begin{array}{c}\text { Ideal } \\
\text { scores }\end{array}$} & \multirow{2}{*}{$\begin{array}{c}\text { Contribution } \\
(\%)\end{array}$} & \multicolumn{2}{|c|}{ NES Implementation } & \multirow{2}{*}{$\begin{array}{l}\text { Gap } \\
(\%)\end{array}$} \\
\hline & & & & Scores & $(\%)$ & \\
\hline Standard 1: Content & 8 & 24 & 11.11 & 22 & 10.18 & 0.93 \\
\hline Standard 2: Process & 10 & 30 & 13.89 & 25 & 11.57 & 2.32 \\
\hline Standard 3: Graduate Competency & 12 & 36 & 16.67 & 35 & 16.2 & 0.47 \\
\hline Standard 4: Educational \& Educational Staff & 11 & 33 & 15.28 & 30 & 13.89 & 1.39 \\
\hline Standard 5: Facilities and Infrastructure & 11 & 33 & 15.28 & 33 & 15.28 & 0 \\
\hline Standard 6: Management & 4 & 12 & 5.56 & 11 & 5.09 & 0.47 \\
\hline Standard 7: Financing & 3 & 9 & 4.17 & 9 & 4.17 & 0 \\
\hline Standard 8: Evaluation & 13 & 39 & 18.06 & 34 & 15.74 & 2.32 \\
\hline TOTAL & 72 & 216 & 100.02 & 199 & 92.12 & 7.9 \\
\hline
\end{tabular}

Based on Table 2, the achievement of eight National Education Standards is $92.12 \%$ with a gap of $7.9 \%$ between the ideal score and school achievements. The biggest gap is found in the process standard and assessment standard which is equal to $2.31 \%$. The process standard is related to the learning process, including teaching materials, teaching media and learning instruments used. The evaluation standard includes the assessment instrument, type of test used, suitability between the assessment instrument and the measured cognitive level. The existence of a gap in the 2 standards indicates that the learning process has not run optimally.

\section{The needs analysis of students and teachers}

This activity used questionnaire and interview sheets. The results of this activity are that the teachers need new innovations in the learning process. The instruments made by the teacher are still in the low-order cognitive skill.

\section{The analysis of national examination absorptive capacity}

The analysis of National Examination data shows a decrease in the absorptive capacity of the national examination in the metabolism topic from the 2014/2015 up to 2016/2017 academic years Table 3 .

Table 3. Data of National Examination absorptive capacity

\begin{tabular}{cccc}
\hline Academic Years & School absorptive capacity (\%) & Regency absorptive capacity (\%) & National absorptive capacity (\%) \\
\hline $2014 / 2015$ & 76,75 & 67,75 & 64.35 \\
$2015 / 2016$ & 42,33 & 49,64 & 47.10 \\
$2016 / 2017$ & 41,46 & 42,29 & 36.83 \\
\hline
\end{tabular}

The decrease in the scores of cell metabolism topic is due to the broad scope of the topic with many stages of chemical reactions so that the students have difficulty understanding the concept. The findings related to the cell metabolism topic underlie the researcher to make this topic as a study of a topic on the research and development product. 


\section{The analysis of teaching materials}

The results of the textbook analysis show that the aspects of the two textbooks do not lead to the indicators related to high-order cognitive skills. The scores obtained for each of the high-order cognitive indicators can be seen in Table 4.

Table 4. Results of teaching material analysis

\begin{tabular}{|c|c|c|c|}
\hline \multirow{2}{*}{ Aspects Assessed } & \multicolumn{2}{|c|}{ Textbooks } & \multirow{2}{*}{ Qualification } \\
\hline & $\overline{A(\%)}$ & B (\%) & \\
\hline Learning objectives & 2.27 & 4.45 & Less \\
\hline Materials & 56.81 & 52.27 & Less \\
\hline Student Activities & 6.81 & 11.33 & Less \\
\hline Evaluation & 43.18 & 43.18 & Less \\
\hline
\end{tabular}

\section{Design}

At the design stage, there are several things to consider; they are: the curriculum used is the 2013 curriculum; the Core Competencies and Basic Competencies used are in accordance with the 2013 curriculum; the module developed consists of the teacher module and student module with cell metabolism topic and based on the Stim-HOTS model.

\section{Development}

The recapitulation of the results of evaluations by expert validators on the draft module based on the StimHOTS model on cell metabolism topic was in the form of quantitative data in the form of percentages and qualitative data in the form of suggestions from expert validators. The results of validation by each expert can be seen in Table 5 and Table 6.

Table 5. Percentage of teacher module evaluations by expert validators

\begin{tabular}{lccc}
\hline \multicolumn{1}{c}{ Validator } & Percentages (\%) & Qualification & Notes: \\
\hline Material expert & 89,28 & Very Good & No need for revisions \\
Module development expert & 94,64 & Very Good & No need for revisions \\
Linguist & 87,50 & Very Good & No need for revisions \\
Learning instrument expert & 87,50 & Very Good & No need for revisions \\
\hline
\end{tabular}

Table 6. Percentage of student module evaluations by expert validators

\begin{tabular}{lccc}
\hline \multicolumn{1}{c}{ Validator } & Percentages (\%) & Qualification & Notes: \\
\hline Material expert & 89,28 & Very Good & No need for revisions \\
Module development expert & 94,64 & Very Good & No need for revisions \\
Linguist & 87,50 & Very Good & No need for revisions \\
Learning instrument expert & 87,50 & Very Good & No need for revisions \\
\hline
\end{tabular}

Based on Table 5 and Table 6 , it can be seen that the teacher module and student module have a percentage between $87-94 \%$ which means that they have very good qualifications. Material validity, module characteristics, learning instruments, design and readability of both modules are sufficient to meet the expected target, but there are some notes from the validators as the revision material.

The suggestions or notes from the validators were used as the revision material including the improvement to writing sentences to fit the enhanced Indonesian spelling system, cover layout setting, cover image setting and the images on the learning activities. A more complete description can be seen in Table 7.

Table 7. Suggestions and results after revision of teacher and student modules

\begin{tabular}{|c|c|c|}
\hline Expert validation & Suggestion & Initial Product Revision \\
\hline Material expert & $\begin{array}{l}\text { The setting of the distance between images at } \\
\text { the orientation stage should be corrected so } \\
\text { that the meaning is not ambiguous } \\
\text { - The image on the module map should be } \\
\text { enlarged to make it clear } \\
\text { - The spelling errors should be corrected in some } \\
\text { parts of the module } \\
\text { - The sentences or instructions should be made } \\
\text { into points to make them not too long } \\
\text { - In the enzyme topic, a brief discussion of } \\
\text { isozymes should be added }\end{array}$ & $\begin{array}{l}\text { - The distance between images at the } \\
\text { orientation stage has been fixed } \\
\text { - The image on the module map has been } \\
\text { enlarged } \\
\text { - The spelling errors in some parts of the } \\
\text { module have been corrected } \\
\text { - The sentences of instructions or instructions } \\
\text { have been made into points } \\
\text { - The topic about isozymes has been added }\end{array}$ \\
\hline
\end{tabular}




\begin{tabular}{|c|c|c|}
\hline Expert validation & Suggestion & Initial Product Revision \\
\hline $\begin{array}{l}\text { Module } \\
\text { development expert }\end{array}$ & $\begin{array}{l}\text { - The image source in the cover and title page } \\
\text { layout should be included } \\
\text { - The purpose of the lab work should be added in } \\
\text { practical activities }\end{array}$ & $\begin{array}{l}\text { - The image source used in the cover and title } \\
\text { page layout has been included } \\
\text { - The purpose of the lab work in practical } \\
\text { activities has been added }\end{array}$ \\
\hline $\begin{array}{l}\text { Learning instrument } \\
\text { expert }\end{array}$ & $\begin{array}{l}\text { - The forewords for the teacher module and } \\
\text { student module should be distinguished } \\
\text { - The instructions for using the module should be } \\
\text { preceded by a command word and should not } \\
\text { be ended with a fullstop (.) }\end{array}$ & $\begin{array}{l}\text { - The forewords for the teacher module and } \\
\text { student module have been distinguished } \\
\text { - The instructions for using the module have } \\
\text { been improved }\end{array}$ \\
\hline Linguist & $\begin{array}{l}\text { - Fix syllabus tables to } 1 \text { page } \\
\text { - } \text { Fix sentence order according to enhanced } \\
\text { Indonesian spelling system }\end{array}$ & $\begin{array}{l}\text { The syllabus table has been improved } \\
\text { - The sentence arrangement has been adjusted } \\
\text { to enhanced Indonesian spelling system }\end{array}$ \\
\hline
\end{tabular}

\section{Implementation}

Test results of education practitioners and student groups

The recapitulation of the results of assessments by education practitioners and groups of students on the draft modules based on the Stim-HOTS model on cell metabolism topic can be seen in Table 8.

Table 8. Percentage of assessment of education practitioners and students

\begin{tabular}{ccc}
\hline Validator & Percentages (\%) & Qualification \\
\hline Practitioner I & 98,36 & Very Good \\
Practitioner II & 98,21 & Very Good \\
Students (12) & 83,44 & Very Good \\
\hline
\end{tabular}

Based on Table 8, it can be seen that the module based on the Stim-HOTS model developed on cell metabolism topic shows the percentage in the range of $83-98 \%$ which means that it has very good qualifications. However, there are some suggestions from practitioners and students related to the systematic writing of questions and image size of the module. The description and results of the revision can be seen in Table 9.

Table 9. Suggestions and results after revision of teacher and student modules

\begin{tabular}{cll}
\hline Giver of advice & \multicolumn{1}{c}{ Suggestion } & \multicolumn{1}{c}{ Second Product Revision } \\
\hline Practitioner & The systematics of the question writing need to be corrected & $\begin{array}{l}\text { The systematics of the question writing has } \\
\text { been fixed }\end{array}$ \\
Student & The size of the image should enlarged to make it clearer & The image has been enlarged \\
\hline
\end{tabular}

Based on the recapitulation of the results of the module evaluations by validators, practitioners and groups of students, as a whole the module based on the Stim-HOTS model developed on cell metabolism material is feasible to be used in the learning process as an effort to empower high-order cognitive skills of students in Surakarta Public Senior High School. The modules based on the Stim-HOTS model developed are divided into 2 namely teacher module and student module. The teacher module is composed of instructions for implementing learning including lesson plans and syllabus, procedures for using modules in detail, details of the syntax of the Stimulating Higher Order Thinking Skill (Stim-HOTS) model and answer signs.

The student module is composed of student activity sheets, material summaries and exercises that refer to empowering high-order cognitive skills of students. The module content is very influential on the quality of the module and the expected process of achieving competencies. The interesting module content with attractive colour composition can motivate the students to learn. Besides, the material presented along with appropriate images helps them understand the concepts learned (Suciyati \& Adian, 2018). The student activities in the module in each Stim-HOTs syntax focus on the process of stimulating high-order cognitive skills and are supported by evaluation questions to measure the achievement of the measured competencies (Sajidan \& Afandi, 2017). The empowerment of high-order cognitive skills is stated in The Law of the Republic of Indonesia No. 20 (2003) that students have the potential to become critical, creative and independent human beings along the times. The effort to develop a biology module based on Stim-HOTS model to empower high-order cognitive skills is expected to be a solution that can be done by educators or teachers in the learning process.

\section{CONCLUSION}

The development of modules based on the Stim-HOTS model on cell metabolism topic in Surakarta Public Senior High School was based on the results of the analysis of teaching materials used in schools which showed that the teaching material had not facilitated the students to achieve the competency of high-order 
cognitive skills optimally. The results of the analysis show that the teaching materials have not facilitated the students in achieving competencies in the form of high-order cognitive skills optimally. The Stimulating Higher Order Thinking Skills (Stim-HOTS) model is a model designed to stimulate thinking skills, one of which is highorder cognitive skills. The module was developed through the validation stage of the expert first to see the feasibility of the module before implemented in the school. Based on the results of the validation, the module based on the Stim-HOTs model on metabolism topic shows the percentage of $83-98 \%$ meaning that it has very good or appropriate qualification to be used to empower students' high-order cognitive skills.

\section{ACKNOWLEDGMENT}

The researcher would like to thank the Institute for Research \& Community Service of Universitas Sebelas Maret which provided funding support for PNBP research under contract No.543/UN27.21/PP/2018.

\section{REFERENCES}

Ahn, R., \& Class, M. (2011). Student-centered pedagogy: Co-construction of knowledge through studentgenerated midterm exams. International Journal of Teaching and Learning in Higher Education, 23(2), 269-281. Retrieved from http://www.isetl.org/ijthe/pdf/IJTLHE1023.pdf

Anderson, L. ., \& Karthwohl, D. . (2001). A taxonomy for learning, teaching and assessing: a revision of blooms taxonomy of educational objective (2nd ed.). Newyork: Addison Wesley Longman, Inc. Retrieved from https://www.uky.edu/ rsand1/china2018/texts/Anderson-Krathwohl\%20-\%20A\%20taxo nomy $\% 20$ for $\% 20$ learning\%20teaching\%20and\%20assessing.pdf

Arikunto, S. (2012). Dasar-dasar evaluasi pendidikan, edisi 2. Jakarta: Bumi Aksara. Retrieved from https:/l scholar.google.co.id/scholar?hl=id\&as_sdt=0,5\&cluster=16929531626349983489

Bächtold, M. (2013). What do students "construct" according to constructivism in science education? Research in Science Education, 43(6), 2477-2496. doi: https://doi.org/10.1007/s11165-013-9369-7

Branch, R. M. (2009). Instructional design: The ADDIE approach. New York: Springer. doi: https://doi.org/ 10.1007/978-0-387-09506-6_3

Connell, G. L., Donovan, D. A., \& Chambers, T. G. (2016). Increasing the use of student-centered pedagogies from moderate to high improves student learning and attitudes about biology. CBE Life Sciences Education, 15(1), 1-15. doi: https://doi.org/10.1187/cbe.15-03-0062

Daryanto. (2013). Menyusun modul: Bahan ajar untuk persiapan guru dalam mengajar. Yogyakarta: Gava Media. Retrieved from https://scholar.google.co.id/scholar?hl=id\&as_sdt=0\%2C5\&q=Menyusun+Modul+ Bahan+Ajar+Untuk+Persiapan+Guru+Dalam+Mengajar\&btnG=

Dhamija, N., \& Kanchan. (2014). Effectiveness of self learning modules on the achievement and retention of undergraduate students in commerce. Educationia Confab, 3(2), 26-32. Retrieved from https://pdfs. semanticscholar.org/70ae/04fc996a22d683f19b34e0899a8faa5b6938.pdf

Fisher, K. M. (2010). Elaboration of cognitive knowledge of biology from childhood to adulthood. The Journal of General Psychology, 112(4), 389-397. doi: https://doi.org/10.1080/00221309.1985.9711027

Hasan, M., Naomee, I., \& Bilkis, R. (2013). Reflection of Bloom'S revised taxonomy in the social science questions of secondary school certificate examination. The International Journal of Social Sciences, 14(1), 47-56. Retrieved from http://www.tijoss.com/TIJOSS 14th Volume/5mahbub.pdf

Istiningrum, R. B., \& Wiyantoko, B. (2017). Improvement of learning outcomes inorganic chemistry through cooperative learning approach types student teams-achievement divisions with the help of molymod props. International Journal of Chemistry Education Research, 1(1), 13-23. doi: https://doi.org/10.20885 lijcer.v1i1.9914

Jabbour, K. K. (2013). Issues that restrain teachers from adapting student-centered instruction in Lebanese school. Tejuelo, 17(2), 85-96. Retrieved from https://dialnet.unirioja.es/descarga/articulo/4353130.pdf

Keengwe, J., Onchwari, G., \& Onchwari, J. (2009). Technology and student learning: Toward a learnercentered teaching model. AACE Journal, 17(171), 11-22. Retrieved from www.researchgate.net/publica tion/255567367\%0ATechnology

Lak, M., Soleimani, H., \& Parvaneh, F. (2017). The effect of teacher-centeredness method vs. learnercenteredness method on reading comprehension among Iranian EFL learners. Journal of Advances in English Language Teaching, 5(1), 1-10. Retrieved from http://european-science.com/jaelt/article/down load/4886/2415

Leward, B. C., \& Hirata, D. (2011). An overview of 21 century skills: Summary of 21st century skills for 
students and teachers. Retrieved from http://www.ksbe.edu/_assets/spi/pdfs/21st_Century_Skills_Bri ef.pdf

Masek, A. (2019). Mode and dimension of facilitation in student-centred learning approach: A comparison of teaching experience. International Journal of Active Learning, 4(1), 24-32. doi: https://doi.org/10.15294/ ijal.v4i1.13172

Mwanda, G. (2017). Towards adoption of constructivist instructional approach in learning biology in secondary school students in Kenya: Addressing learner attitude. International Journal of Secondary Education, 5(1), 1-11. doi: https://doi.org/10.11648/j.ijsedu.20170501.11

Pramesti, B., Sajidan, S., \& Dwiastuti, S. (2018). Stimulating higher-order thinking skills (HOTs) with the module on metabolism topic at the senior high school in Surakarta. In Proceedings of the International Conference on Teacher Training and Education 2018 (ICTTE 2018) (Vol. 262, pp. 315-318). Paris, France: Atlantis Press. doi: https://doi.org/10.2991/ictte-18.2018.58

Prastowo, A. (2011). Panduan kreatif membuat bahan ajar inovatif. Yogyakarta: Diva Press. Retrieved from https://scholar.google.co.id/scholar?hl=id\&as_sdt=0,5\&cluster=4815026233283437591

Rufii, R. (2015). Developing module on constructivist learning strategies to promote students' independence and performance. International Journal of Education, 7(1), 18. doi: https://doi.org/10.5296/ije.v7i1.6675

Sajidan, \& Afandi. (2017). Pengembangan model pembelajaran IPA untuk memberdayakan keterempalian berfikir tingkat tinggi. In SEMINAR NASIONAL PENDIDIKAN SAINS "Strategi Pengembangan Pembelajaran dan Penelitian Sains untuk Mengasah Keterampilan Abad 21 (Creativity and Innovation, Critical Thinking and Problem Solving, Communication, Collaboration/4C) "Universitas Sebelas Maret (pp. 15-27). Surakarta. Retrieved from http://jurnal.fkip.uns.ac.id/index.php/snps/article/viewFile/11366/ 8068

Saputri, A. C., Sajidan, S., Rinanto, Y., Afandi, A., \& Prasetyanti, N. M. (2019). Improving students' critical thinking skills in cell-Metabolism learning using stimulating higher order thinking skills model. International Journal of Instruction, 12(1), 327-342. doi: https://doi.org/10.29333/iji.2019.12122a

Serrat, M. A., Dom, A. M., Buchanan, J. T., Williams, A. R., Efaw, M. L., \& Richardson, L. L. (2014). Independent learning modules enhance student performance and understanding of anatomy. Anatomical Sciences Education, 7(5), 406-416. doi: https://doi.org/10.1002/ase.1438

Singh, S., \& Yaduvanshi, S. (2015). Constructivism in science classroom: Why and how. International Journal of Scientific and Research Publications, 5(3), 1-5. Retrieved from http://www.ijsrp.org/research-paper0315/ijsrp-p3978.pdf

Stanny, C. (2016). Reevaluating Bloom's taxonomy: What measurable verbs can and cannot say about student learning. Education Sciences, 6(4), 37. doi: https://doi.org/10.3390/educsci6040037

Stayanchi, J. (2017). Higher order thinking: Bloom's taxonomy. Kwansei Gakuin University Humanities Review, 22, 117-124. Retrieved from https://kwansei.repo.nii.ac.jp/?action=repository_action_common _download\&item_id=26444\&item_no=1\&attribute_id=22\&file_no=1

Suciyati, A., \& Adian, T. (2018). Developing the fun and educative module in plant morphology and anatomy learning for tenth graders. JPBI (Jurnal Pendidikan Biologi Indonesia), 4(1), 53-60. doi: https://doi.org/ 10.22219/jpbi.v4i1.5334

Suhendi, A., \& Purwarno. (2018). Constructivist learning theory: The contribution to foreign language learning and teaching. KnE Social Sciences, 3(4), 87-95. doi: https://doi.org/10.18502/kss.v3i4.1921

Suwastono, A. (2011). Pengembangan pembelajaran e-learning berbasis moodle pada mata kuliah penginderaan jauh S1 Jurusan Geografi. Pascasarjana Universitas Negeri Malang, Malang. Retrieved from https://scholar.google.co.id/scholar?hl=id\&as_sdt=0,5\&cluster=6244928361058312649

The Law of the Republic of Indonesia No.20 Year. (2003). National Education System. Chapter 1 Article 1 Line 20. Retrieved from http://www.flevin.com/id/lgso/translations/Laws/Law No. 20 of 2003 on the National Education System (BKPM).pdf

Usmeldi, U. (2018). The effectiveness of research-based physics learning module with predict-observeexplain strategies to improve the student's competence. In Journal of Physics: Conference Series (Vol. 1013, p. 012041). doi: https://doi.org/10.1088/1742-6596/1013/1/012041 